\title{
Disharmony of Regional Bond Issuance Guarantee
}

\author{
Samsul Arifin \\ Students of the Doctoral Study Program in Law, Universitas Lampung, Bandar Lampung, Indonesia
}

International Seminar on Foreign Investment Law in Indonesia-Muhammadiyah University Metro-28 October 2021

\begin{abstract}
Regional bonds are an alternative for local governments to obtain funds to finance regional development. In the process of issuing bonds, collateral is needed in the form of regional assets to ensure the fulfillment of investors' rights. Although the guarantee for the issuance of regional bonds has been regulated in Article 55 of Law no. 33 of 2004 concerning Fiscal Balance between the Central Government and Regional Governments, its implementation will be difficult to do because there is a prohibition on confiscation of state assets as regulated in Article 50 of Law No.1 of 2004 concerning State Treasury. This paper aims to examine the disharmony of the regulation on guarantees in the issuance of regional bonds. Based on the discussion, it can be concluded that the issue of disharmony related to guarantees in regional bonds can be answered by making legal discoveries, namely by identifying and interpreting the relevant regulations. If the regional government acts in its capacity as a public legal entity that carries out civil actions, it must comply with the provisions of civil law. Regional assets that are used as collateral in the issuance of regional bonds are state-owned assets classified as separated stateowned assets so that the regional government assets are no longer attached to state property, and if there is a default on regional bonds, these assets can be confiscated for auction. to fulfill the rights of investors by setting aside the provisions of Article 50 of the State Treasury Law.
\end{abstract}

Keywords: regional onds, guarantees, regional assets

DOI: $10.7176 / J L P G / 115-08$

Publication date: November $30^{\text {th }} 2021$

\section{Introduction}

Regional autonomy aims to accelerate the realization of welfare for the community through improving the quality of public services. Empowerment and community participation are also expected to optimize the empowerment of existing resources in the region for the prosperity of the community. One of the rationales behind the issuance of the regional autonomy law is so that the regions can regulate and manage their government affairs according to the principles of autonomy and co-administration. Since the implementation of regional autonomy, local governments have had the freedom to develop their regions. Therefore, regional economic development in the era of regional autonomy is very dependent on how the Regional Government plans its regional activities. ${ }^{1}$ However, judging from the APBD posture, the main source of regional funding is still largely dependent on the central government, especially from balancing funds (consisting of General Allocation Funds, Revenue Sharing Funds and Special Allocation Funds) amounting to 60\% of regional revenues. ${ }^{2}$ To encourage regions to increase their regional capacity, the central government has established a general policy on regional transfers with the aim that regional governments can explore their own regional revenue. Other policies that are being encouraged are reducing the disparity in sources of government funding between the center and the regions as well as financing autonomy, among others, by issuing regional bonds.

Bonds are one type of securities (securities) traded in the capital market in the form of certificates of proof of debt issued by a limited liability company or certain institutions, both government and other institutions to obtain funds or capital. Bonds are traded in the public through a public offering, the issuer agrees to pay a fixed amount of interest for a certain period and will repay the principal at maturity. ${ }^{3}$ Bonds are alternative financing for the government and private companies because banking institutions have not been able to meet all the capital requirements needed by business actors and the government. Bonds can be issued either by the government or by the private sector. Government bonds include bonds issued by the central government (government bonds) and bonds issued by local governments (municipal bonds). Meanwhile, bonds issued by private companies are known as corporate bonds.

Regional bonds are one type of regional debt as regulated in Government Regulation Number 30 of 2011 concerning regional loans. Regional bonds in the form of debt securities issued by local governments are offered

\footnotetext{
${ }^{1}$ Abdul Hamid, Otonomi Daerah Dan Kualitas Pelayanan Publik, Jurnal Academica Fisip Untad vol.03 no. 01 Februari 2011

${ }^{2}$ Metasari Kartika, Transfer Pusat dan Upaya Pendapatan Asli Daerah (Studi kasus Kabupaten/Kota di Kalimantan Barat), Jurnal Ekonomi Bisnis dan Kewirausahaan 2015, Vol. 4, No. 1, 45-71

${ }^{3}$ Husaini dan Saiful, "Pengaruh Penerbitan Obligasi Terhadap Risiko dan Return Saham", Jurnal Manajemen dan Bisnis, Vol. 5 No. 1, p. 3546
} 
to the public through public offerings in the capital market. Regional bonds are not guaranteed by the Central Government so that all risks arising from the issuance of regional bonds are the full responsibility of the regional government. In terms of regulation, the provisions governing the issuance of regional bonds have been regulated since the promulgation of Law Number 22 of 1999 concerning Regional Government and Law Number 25 of 1999 concerning Financial Balance between the Center and Regions. Where the two laws have regulated the utilization of potential resources in the region, including exploring the potential for financing by issuing bonds.

Bonds are debt acknowledgments and what distinguishes bonds from ordinary debts are the parties involved. Wirjono Prodjodikoro stated that bonds are "signs that one person participates in lending money to the company together with other people who accept receivables from the company. ${ }^{1}$ A debt agreement, generally takes place between one debtor and one creditor, while in bonds one debtor is dealing with several creditors whose numbers can be hundreds, thousands, even tens of thousands. Due to the nature of such bonds, the bond issuance process is carried out through a public offering and this is the main feature of bond issuance and marketing.

The legal relationship between bond issuers and investors arises from a debt agreement. Issuers of debt securities (bonds) act as debtors, while investors who buy debt securities act as debtors (creditors). In terms of debt and receivables, it is mandatory to have a guarantee to provide legal certainty to creditors that the debtor will carry out his obligations.

Guarantees are divided into two forms, namely general guarantees and special guarantees. General guarantees are guarantees as regulated in Articles 1131 and 1132 of the Civil Code. A general guarantee means that if the parties do not make a guarantee agreement specifically, it does not mean that the law does not provide legal protection and certainty that the debtor is obliged to pay. Article 1131 stipulates that all debtor's assets, both movable and immovable, both existing and those that will exist in the future, serve as collateral for all debtor engagements, and Article 1132 of the Civil Code stipulate that all such objects serve as collateral for all debtors. creditors by paying attention to the balance in the distribution. While special guarantees are guarantees that are regulated in an agreement made by the parties to bind a person or an asset to be used as a guarantee that the debtor will carry out his obligations, and if it is not implemented, then the agreed guarantee serves to ensure that the creditor gets what he is entitled to. This special guarantee can be in the form of either individual guarantees (guaranteed/borgtocht) or material guarantees. ${ }^{2}$

Concerning guarantees in the issuance of regional bonds, the provisions regarding this matter can be found in Article 55 paragraph 3 of Law no. 33 of 2004 concerning Fiscal Balance between the Central Government and Regional Governments which reads "Projects financed from Regional Bonds and regional property attached to the project can be used as collateral for Regional Bonds". Regional assets and regional income are not allowed to be used as collateral for regional loans, but to provide legal protection for investors' rights, in issuing bonds, regional governments can guarantee their assets embedded in development/investment projects as a form of government participation.

The regulation on guarantees in the issuance of bonds above is still not enough to provide a sense of security for investors, this happens because the process of confiscation and execution of collateral objects in the event of a regional bond default will be difficult to carry out. Law No. 1 of 2004 concerning Regional Treasury prohibits the confiscation of guarantees and confiscation of state property. The prohibition of confiscation and auction of state property as regulated in Article 50 of the State Treasury Act becomes an obstacle in the process of settling local government debt in the event of a regional bond default. This puts a very detrimental condition for investors because there is no guarantee of the fulfillment of investors' rights.

\section{Discussion}

Regional bonds are one type of regional loan that aims to accelerate regional economic growth and improve services to the community. A bond is proof of debt to a certain party that must be repaid within a predetermined period. Usually, loans with these bonds have maturities of more than one year. Regional bonds have the same meaning as bonds in general where the party that issues is the local government, and the party who buys it is the community through transactions in the capital market.

Like two sides of a coin, in addition to the various benefits above, the region that issues bonds will also receive a consequence to pay off the principal debt and interest. Therefore, the issuance of regional bonds must be based on existing legal regulations. According to Law no. 32 of 2004 article 169 paragraph 2 states that "Local governments with the approval of the DPRD can issue regional bonds to finance investments that generate revenue". With this regulation, it is clear that regions may only issue bonds whose funds will be used to finance development projects that generate revenue. ${ }^{3}$

\footnotetext{
${ }^{1}$ Wirjono Prodjodikoro,, Hukum Perkumpulan, Perseroan dan Koperasi, Pradnya Paramitha, Jakarta, 1985, p. 170

${ }^{2}$ Lastuti Abubakar, Telaah Yuridis Perkembangan Lembaga Dan Objek Jaminan (Gagasan Pembaruan Hukum Jaminan Nasional), Buletin Hukum Kebanksentralan • Volume 12, Nomor 1, Januari - Juni 2015

${ }^{3}$ Rizky fitria, Menanti Kesiapan Daerah Menerima Kesempatan Dan Tantangan Penerbitan Obligasi Daerah SebagaiAlternatif Pembiayaan, Jurnal Wacana Kinerja volume 13 no.2 November 2010 (261-275)
} 
In measuring the risk of regional bonds, prospective issuers (local governments) and potential investors must understand their characteristics, including the risks involved. Although very minimal, regional bonds have the risk of default. Reflecting on the bankruptcy of Detroit, the city that was previously the basis of the automotive industry in the United States had to file for bankruptcy in mid-2013 because of the large debt of Rp. 180 trillion. In addition to the amount of debt, the Detroit government, which is suspected of being mentally corrupt, adds to the blacklist of the failure of one of the cities in America. However, cases of default on municipal bonds in the United States have a very small percentage. Based on 10 years of cumulative data on municipal bonds rated A or AA, only $0.03 \%$ failed to pay. This means that only 3 regional bonds out of 10,000 regional bonds have defaulted. ${ }^{1}$

Although the possibility is very small, the potential for default has been anticipated by the government. Some forms of anticipation carried out by the government are:

1. The Central Government may deduct DAU and DAK to pay bond installments if the Regional Government fails to pay.

2. The existence of a rating or regional ranking carried out by an independent institution. The results of the rating will be used as an illustration for potential investors who will buy regional bonds. The rating can describe the return that will be received after seeing the potential risks.

3. Issuance of regional bonds is adjusted to the ability or fiscal capacity of the region. This means that the issuance of regional bonds must be based on the real needs and ability of the regions to pay bonds. The maximum capacity of regions in issuing bonds can be seen by comparing the real number of bonds issued with the total APBD or Regional GDP

4. Issuance of regional bonds is routinely audited by an independent institution. Considering that the issuance of regional bonds is subject to two legal umbrellas, namely the legislation on regional finance and the Capital Market Law, the audit is carried out by two parties, namely the Public Accounting Firm and the Supreme Audit Agency.

The ability of local governments to fulfill their obligations after issuing bonds will be reflected in the ratings that will be given by independent rating agencies. The high or low rating will be influenced by several factors, including the guarantee or underlying provided by the local government acting as the bond issuer. ${ }^{2}$ This rating will later become a reference for the public as investors decide their investment in regional bonds issued by some local governments. The guarantee provided by the regional government is an important factor that affects the amount of public trust to invest their funds in regional bonds.

In the law of guarantees, there are general guarantees and special guarantees. General Guarantee includes all current or future assets of the debtor, which can be used as collateral for debt repayment. General Guarantees are difficult to execute because the object of property to be executed is not specific. General Guarantees are also difficult to execute because many creditors are fighting over the right to execute. To overcome this problem, the Law of Guarantee is also known as the Special Guarantee. General Guarantees are regulated in Article 1131 of the Civil Code which states "all debtor assets, both movable and immovable, both existing and those that will only exist in the future, become dependents for all individual engagements". Based on this, all current and future assets of the debtor can be used as debt collateral even though the debt-receivable agreement is not followed by a guarantee agreement. General guarantees are used, among others, in the issuance of debt securities in the form of bonds in the capital market or commercial paper in the money market.

Special Guarantees consist of individual guarantees and material guarantees. Individual Guarantee or Guarantee (borgtocht) is regulated in Article 1820 of the Civil Code which states "Insurance is an agreement by which a third party, for the benefit of the debtor (the creditor), binds himself to fulfill the debtor's (debtor) engagement when this person himself does not fulfill it". Individual guarantees are fully regulated in Article 1820 to Article 1850 of the Civil Code. Non-material guarantees can be in the form of personal guarantees, corporate guarantees, or state/government guarantees.

Guarantees in bond issuance vary greatly depending on the contract made. For example, in mortgage bonds, bonds are guaranteed by certain assets, which are immovable objects. And if there is a default on the bonds, the assets that are guaranteed will be auctioned to fulfill the rights of investors. In the case of the issuance of regional bonds in the form of guarantees that can be provided by the regional government as the issuer, it can be in the form of the credibility of the regional government, income from projects financed with bond funds, or in the form of regional government assets attached to projects financed with regional bonds.

The juridical guarantee function is the legal certainty of debt repayment in the debt agreement. While the guarantee in financing has a function, namely to pay debts in case of default, namely by cashing or selling the guarantee. As a result of the first indicator, namely the determination of the amount of financing or debt loans to

${ }^{1}$ Cita Yustisia Serfiyani, Kajian Hukum Penerbitan Dan Penyelesaian Sengketa Obligasi Daerah, JurnalLegislasi IndonesiaVol 15 No.2 Juli $2018: 9-25$

${ }^{2}$ Rezha Hadyan, Aturan aset dasar dalam penerbitan obligasi daerah akan direlaksasi, https://investasi.kontan.co.id/news/aturan-aset-dasardalam-penerbitan-obligasi-daerah-akan-direlaksasi [Acessed on January 12, 2021 12:35] 
be given to debtors. And convince the bank or creditor that the debtor can pay off the debt given to him as agreed. $^{1}$

Seizures and auctions of collateral in accounts payable are the last resort in resolving disputes that arise. Seizure and auction of collateral are carried out if the debtor is unable to fulfill his obligations and other settlement efforts cannot resolve the problems that arise, the guarantee will be auctioned to fulfill the rights of creditors. The definition of confiscation in civil cases is that the court's legal action precedes the subject matter or precedes the decision. ${ }^{2}$ The regulation regarding this confiscation can be found in Article 227 in conjunction with Article 261 in conjunction with Article $206 \mathrm{RBg}$. Security confiscation is the confiscation of the defendant's goods or disputed goods to be used as collateral while the case examination process is in progress. ${ }^{3}$ The problem is, can there be confiscation of state property?

In regional bonds confiscation and auction of collateral will be difficult to carry out, this is because confiscation and auction of regional assets are prohibited. Article 50 of Law No.1 of 2004 concerning the State Treasury states that any party is prohibited from confiscation of:

a. Money or securities belonging to the state/region, both those with government agencies and with third parties;

b. Money that must be deposited by a third party to the state/region.

c. Movable goods belonging to the state/region, both those in government agencies and third parties;

d. Movable goods and other property belonging to the state/region;

e. Goods belonging to third parties that are paid off by the state/region that is needed for the implementation of government duties.

The purpose of the law is to realize justice will be realized if every regulation is made in harmony and harmony. The process of harmonization of law is a mandatory thing to do so that the legislation is in accordance with the principles of law and good legislation. Legal harmonization is the process of adjusting laws and regulations, government decisions, judges' decisions, the legal system, and legal principles with the aim of increasing legal unity, legal certainty, justice (justice, gerechtigheid) and comparability (equity, billijkeid), usefulness and clarity of the law., without obscuring and compromising legal pluralism if it is necessary. ${ }^{4}$ Conceptually, harmonization of the legal system can be carried out as a whole which will involve a chain of relationships between three components of the legal system, namely legal substance, legal structure and institutions, and legal culture..$^{5}$ Thus, legal harmonization is an effort or process to overcome the boundaries of differences, contradictory matters, and irregularities in the law, so that legal norms in-laws and regulations as a subsystem in a unified framework of the legal system are not hindered by differences, do not conflict with each other, and do not duplicate or overlap. ${ }^{6}$

The problem of disharmony of regulations regarding guarantees in the issuance of regional bonds can be started with the alignment and harmonization of the objectives, strategies, and guidelines for the issuance of regional bonds, namely to assist local governments in financing the development of public facilities and infrastructure for the benefit of the wider community while taking into account the protection of rights and interests. community investors. The legal harmonization process is carried out through legal interpretation, legal construction, reasoning, and rational argumentation while taking into account the legal system and legal principles.

As for what can be done in the context of harmonization of regulations for the issuance of regional bonds, it is started by identifying disharmony between the arrangements regarding general guarantees as regulated in Article 1131 of the Civil Code and special guarantees for the issuance of regional bonds as regulated in Article 55 of Law no. 33 of 2004 concerning Fiscal Balance between the Central Government and Regional Governments with provisions concerning the prohibition of confiscation of state assets as regulated in Article 50 of Law No.1 of 2004 concerning the State Treasury. After identification, legal discovery efforts are made using the interpretation method, and legal construction is carried out referring to the provisions of civil law, especially contract law, where if there has been a contractual agreement between the government and bond investors, the government's obligation to complete the agreement cannot be ruled out. ${ }^{7}$

Efforts to find a law to find a solution to the problem of disharmony in regulations related to the confiscation of regional bond guarantees, we must re-examine the position of local governments as state

\footnotetext{
${ }^{1}$ Fungsi Jaminan Dalam Pemberian Kredit, Gregoryo Terok, Lex Privatum, Vol.I/No.5/ November/ 2013

${ }^{2}$ Yahya Harahap,1990. Permasalahan dan Penerapan Sita Jaminan Coservatori Beslag, Pustaka, Bandung, p 5

${ }^{3}$ Mohammad Effendi, Implikasi Penyitaan Barang-barang Milik Negara dan Konsekuensi Hukumnya, UNISIA, Vol. XXX No. 66 December 2007.

${ }^{4}$ Suhartono, Harmonisasi Peraturan Perundang-Undangan Dalam Pelaksanaan Anggaran Belanja Negara (Solusi Penyerapan Anggaran Belanja Negara Yang Efisien, Efektif Dan Akuntabel), Thesis, Jakarta: Universitas Indonesia, 2011, p. 94.

${ }^{5}$ Ibid, h.6

${ }^{6}$ Ibid, h.9

${ }^{7}$ Desak Putu Dewi Kasih dan Ni Putu Purwanti, Obligasi Daerah Dalam Kerangka Hukum Keuangan Negara, Acta Comonitas Jurnal Hukum Kenotariatan, Vol. 3 No. 2 October 2018
} 
institutions that can act in a public and private framework. If the regional government acts in its capacity as a Public Legal Entity that carries out civil actions, then it must comply with the provisions of civil law. If the government is negligent in carrying out its obligations in fulfilling investors' rights, the government can be sued through courts, and confiscation and auctions of regional assets that are used as guarantees for the issuance of regional bonds can be carried out by ignoring the provisions of Article 50 of the State Treasury Law. ${ }^{1}$

In addition to looking at the position of local governments in the legal discovery process, we also need to look at the position of regional assets. In the theoretical concept, state assets are assets that are in the scope of the public sphere (public-private), so that their management and accountability are subject to the provisions of laws and regulations publicly. Juridically-normatively, state assets are divided into three sub-state assets, namely: ${ }^{2}$

1) Assets managed by the government themselves are called State-Owned Goods (BMN), for example, land and buildings of Ministries/Institutions, cars owned by Ministries/Institutions;

2) Assets managed by other parties are called separated state assets, for example, state capital participation in the form of shares in BUMN, or initial assets in various state-owned legal entities (BHMN) which are declared as separate assets based on the law of their establishment.

3) State-controlled assets in the form of potential wealth related to earth, water, air, and natural resources contained therein which are controlled by the state as the highest organization, for example, mining, coal, oil, geothermal, ex-foreign nationalization assets, and reserves. culture.

Based on the classification of the types of state assets above, regional assets that are used as collateral in the issuance of regional bonds fall into the second category, namely separated state assets. According to Yahya Harahap, the confiscation of money and property belonging to the state or region is prohibited. ${ }^{3}$ In this regard, if an asset belonging to a regional government has been used as collateral in the issuance of regional bonds, then the regional government asset is no longer attached to the element of state property because it has been specifically agreed that the asset is used as collateral for the fulfillment of the rights of investors who are subject to provisions of civil law, and is no longer subject to public law. Therefore, regional government assets that have been used as collateral for the issuance of regional bonds are subject to the provisions of civil procedural law.

\section{Conclusion}

The disharmony of regulations relating to the guarantee provisions as regulated in Article 1131 of the Civil Code and Article 55 of Law no. 33 of 2004 concerning Fiscal Balance between the Central Government and Regional Governments with provisions concerning the prohibition of confiscation of state assets as regulated in Article 50 of Law No. 1 of 2004 concerning State Treasury can be resolved by making legal discoveries by identifying and interpreting all provisions that related. Efforts to harmonize regulations relating to guarantees in the issuance of regional bonds are carried out by examining the position of regional governments and regional assets that are used as collateral. Based on the discussion above, we can conclude that: If the local government acts in its capacity as a Public Legal Entity that carries out civil actions, it must comply with the provisions of civil law. Regional assets that are used as collateral in the issuance of regional bonds are state-owned assets that are classified as separated state-owned assets so that the regional government assets are no longer attached to state property, and if there is a default on regional bonds, these assets can be confiscated for auction. to fulfill the rights of investors by setting aside the provisions of article 50 of the state treasury law.

\section{References}

Dian Puji N Simatupang, 2010, Laporaan Akhir Analisa Dan Evaluasi Peraturan Perundang-Undangan Tentang Aset Negara, Kementerian Hukum Dan Hak Asasi Manusia RI, Badan Pembinaan Hukum Nasional.

Yahya Harahap, 2011, Hukum Acara Perdata tentang Gugatan, Persidangan, Penyitaan, Pembuktian, dan Putusan Pengadilan, Sinar Grafika, Jakarta.

Yahya Harahap,1990. Permasalahan dan Penerapan Sita Jaminan Coservatori Beslag, Pustaka, Bandung.

Wirjono Prodjodikoro, 1985, Hukum Perkumpulan, Perseroan dan Koperasi, Pradnya Paramitha, Jakarta.

Suhartono, 2011, Harmonisasi Peraturan Perundang-Undangan Dalam Pelaksanaan Anggaran Belanja Negara (Solusi Penyerapan Anggaran Belanja Negara Yang Efisien, Efektif Dan Akuntabel), Universitas Indonesia, Jakarta

Abdul Hamid, Otonomi Daerah Dan Kualitas Pelayanan Publik, Jurnal Academica Fisip Untad vol.03 no. 01 Februari 2011

Metasari Kartika, Transfer Pusat dan Upaya Pendapatan Asli Daerah (Studi kasus Kabupaten/Kota di

\footnotetext{
${ }^{1}$ Mohammad Effendi, Implikasi Penyitaan Barang-barang Milik Negara dan Konsekuensi Hukumnya, UNISIA, Vol. XXX No. 66 December 2007

${ }^{2}$ Dian Puji N Simatupang, Laporaan Akhir Analisa Dan Evaluasi Peraturan Perundang-Undangan Tentang Aset Negara, Kementerian Hukum Dan Hak Asasi Manusia Ri Badan Pembinaan Hukum Nasional Tahun 2010

${ }^{3}$ Yahya Harahap,2011, Hukum Acara Perdata tentang Gugatan, Persidangan, Penyitaan, Pembuktian, dan Putusan Pengadilan, Sinar Grafika, Jakarta, p. 324
} 
Kalimantan Barat), Jurnal Ekonomi Bisnis dan Kewirausahaan 2015, Vol. 4, No. 1, 45-71

Husaini dan Saiful, "Pengaruh Penerbitan Obligasi Terhadap Risiko dan Return Saham", Jurnal Manajemen dan Bisnis, Vol. 5 No. 1, p. 35-46

Lastuti Abubakar, Telaah Yuridis Perkembangan Lembaga Dan Objek Jaminan (Gagasan Pembaruan Hukum Jaminan Nasional), Buletin Hukum Kebanksentralan • Volume 12, Nomor 1, January - June 2015

Rizky fitria, Menanti Kesiapan Daerah Menerima Kesempatan Dan Tantangan Penerbitan Obligasi Daerah SebagaiAlternatif Pembiayaan, Jurnal Wacana Kinerja volume 13 no.2 November 2010 (261-275)

CitaYustisiaSerfiyani, KajianHukumPenerbitan Dan Penyelesaian Sengketa Obligasi Daerah, Jurnal Legislasi IndonesiaVol 15 No.2 - July $2018: 9$ - 25

Fungsi Jaminan Dalam Pemberian Kredit, Gregoryo Terok, Lex Privatum, Vol.I/No.5/ November/ 2013

Mohammad Effendi, Implikasi Penyitaan Barang-barang Milik Negara dan Konsekuensi Hukumnya, UNISIA, Vol. XXX No. 66 December 2007.

Desak Putu Dewi Kasih dan Ni Putu Purwanti, Obligasi Daerah Dalam Kerangka Hukum Keuangan Negara, Acta Comonitas Jurnal Hukum Kenotariatan, Vol. 3 No. 2 October 2018

Mohammad Effendi, Implikasi Penyitaan Barang-barang Milik Negara dan Konsekuensi Hukumnya, UNISIA, Vol. XXX No. 66 December 2007

Rezha Hadyan, Aturan aset dasar dalam penerbitan obligasi daerah akan direlaksasi, https://investasi.kontan.co.id/news/aturan-aset-dasar-dalam-penerbitan-obligasi-daerah-akan-direlaksasi [Accessed on January 12, 20211 12:35] 